\title{
COMPARISON OF ALLUVIAL SOILS OF DIFFERENT LAND USE IN THE AREA OF THE NATIONAL PARK "UNA" WITH SPECIAL EMPHASIS ON THE DISTRIBUTION OF CADMIUM, NICKEL AND ARSENIC
}

\author{
Fatima MUHAMEDAGIĆ ${ }^{1 *}$, Mirsad VELADŽIĆ ${ }^{1}, Z_{\text {Żjka }}$ ZGORELEC $^{2}$, \\ Silva ŽUŽUL ${ }^{3}$, Jasmina RINKOVAC ${ }^{3}$
}

\begin{abstract}
The paper presented results of a comparison of alluvial soils of different land use at two sites within the National Park "Una". The sites were related to a natural meadow (BUK) and artificial meadow (KLISA). The main objective of the research, in addition to the physical and chemical parameters of soil quality, was to determine the distribution of the total content of cadmium (Cd), nickel (Ni) and arsenic (As). The total content of these elements were observed in composite samples at two depths of $0-10 \mathrm{~cm}$ and $0-20 \mathrm{~cm}$ and horizons profile. Their total content was measured by atomic AAS. The results were analyzed using Kruskal - Wallis test $(\mathrm{p} \leq 0.05)$ using coefficient $\chi^{2}$. The results showed a single legality of the distribution of Cd, Ni and As in samples of soil profile, while the average soil samples showed unique legality of the distribution of observed elements.
\end{abstract}

Keywords: alluvial soil, distribution, cadmium, nickel, aresenic

\section{INTRODUCTION}

In recent decades the area of the National park „Una“ has stirred the interest of many scientists and researchers (Alibabić and Bašić, 2005; Bašić and Čustović, 2005; Muhamedagić, 2010, etc). In particular, the issues of distribution of toxic elements in the soil have been dealt with, both in our country and the world, by many researchers coming from different functional areas: industrial (Shakeri et al., 2009; Dheeba and Sampathkumar, 2012, etc.), urban (Romić and Romić, 2003, etc.), landfills (Dellantonio et al., 2007, etc.) and protected areas (Maksimović et al., 2013; Muhamedagić, 2015, etc.).

\footnotetext{
${ }^{1}$ Biotehnički fakultet Univerzitet u Bihaću, Luke Marjanovića bb, 77000 Bihać, Bosnia and Herzegovina

${ }^{2}$ Agronomski fakultet, Sveučilište u Zagrebu, Svetošimunska cesta 25, 10000 Zagreb, Croatia

${ }^{3}$ Institute for Medical Research and Occupational Health, Ksaverska cesta 2, HR-10001 Zagreb, Croatia

*Corresponding author: fatima.muhamedagic@gmail.com
} 
This paper presents the results of a comparison of alluvial soils of different use with in the National Park „Una“. The study has placed a special emphasis on the distribution of the total content of cadmium $(\mathrm{Cd})$, nickel $(\mathrm{Ni})$ and arsenic $(\mathrm{As})$ in the average samples $(0-10$ and $0-20 \mathrm{~cm})$ and by depth of the soil profile. Selected research sites were located in the extensions of alluvial plains along the river Una. The first site of BUK (altitude: $284 \mathrm{~m}$ ) and the second site of KLISA (altitude: $301 \mathrm{~m}$ ) (Figure 1-2).
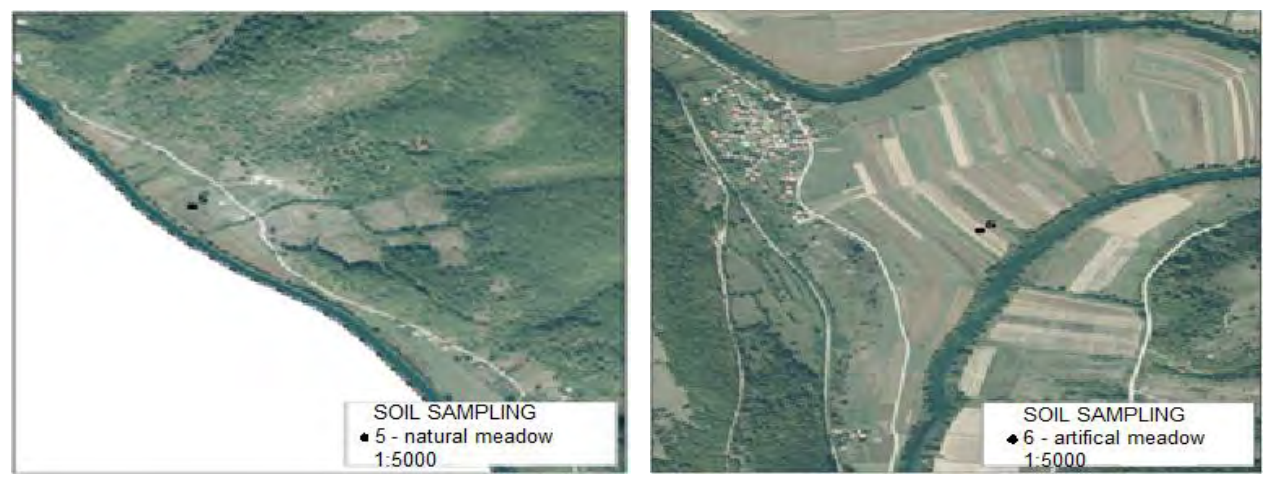

Figure $1-2$. The sites of soil sampling BUK (left) and KLISA (right)

\section{MATERIAL AND METHODS}

This paper presents results of the field research, sampling and laboratory testing. All analyzes of soil samples were determined according to standardized methods: Mechanical composition (ISO 11277); Structure (Method by Sekera); The rights specific gravity, Porosity (ISO 11508); The volume specific gravity (ISO 11272); Actual humidity, Capacity of soil for water and Air capacity (ISO 11465); Humus (ISO 10694); $\mathrm{CaCO}_{3}$ (ISO 10693); $\mathrm{pH}$ (ISO 10390); El. conductivity (ISO 11265); $\mathrm{P}_{2} \mathrm{O}_{5}$ and $\mathrm{K}_{2} \mathrm{O}$ (ISO 19730) and The total content of metals and metalloids in the soil (ISO 11466).

A total of two pedological profiles were opened at the sites of research and average samples were taken from two soil depths: $0-10 \mathrm{~cm}$ and $0-20 \mathrm{~cm}$.

Preparation of soil samples was carried out at the Biotechnical Faculty of the University of Bihać. All analyses of soil samples were carried out in the laboratory of the Institute of Soil Science, Agrochemistry and Reclamation of the Faculty of Agricultural and Food Sciences, University of Sarajevo, except for the content of arsenic that was carried out at the Faculty of Agriculture, University of Zagreb, and the Institute for Medical Research and Occupational Health in Zagreb. Statistical analysis was performed by the Kruskal-Wallis test at the level of significance of $p \leq 0.05$. To determine the relation and distribution of $\mathrm{Cd}, \mathrm{Ni}$ and $\mathrm{As}$ in the soil we used the correlation coefficient $\left(\chi^{2}\right)$ (Kruskal and Wallis, 1952). Data were statistically analyzed using SPSS 17. The maximum allowable amounts of total contents were determined in accordance with the current 
regulations (Official Gazette of the Federation of B\&H, No. 72/90) in relation to the soil texture (MRL) and the use of soil in organic farming (MRL-OF). Used are orthophoto imagery in the scale of 1: 5000 and 1: 75000, topographic maps and GIS.

\section{RESULTS AND DISCUSSION}

Results of the study on the comparison of alluvial soils with different use provide:

Description of the alluvial soil profile at the site of BUK (Figure 3)

- Site: alluvial plain - BUK (N 44 39.042', E $\left.16^{\circ} 01.938^{\prime}\right)$;

- Vegetation: meadow;

- Use: natural meadow no cultivation;

- Parent substrate: alluvium

I $0-11 \mathrm{~cm}$ : surface layer intertwined with roots, brown in colour, with fine granular structure and sandy loam texture ( sand $=68.8 \%$, powder $=16.5 \%$, clay $=14.7 \%$ ).

II 11-51 cm: abrupt transition to a yellowish-brown layer with evident penetration of roots, with fine granular structure and sandy loam texture (sand $=69.0 \%$, powder $=15.2 \%$, clay $=15.8 \%$ ).

III 51-110 cm: gradual transition to a greyish-brown layer, with very fine granular structure and sandy clayey loam texture ( sand $=59.8 \%$, powder $=21.0 \%$, clay $=19.2 \%$ ).

IV $>110 \mathrm{~cm}$ : emergence of groundwater.

Description of the alluvial soil profile at the site of KLISA (Figure 4)

- Site: alluvial plain - KLISA (N 44 $35.115^{\prime}$, E $16^{\circ} 04.487^{\prime}$ )

- Vegetation: meadow;

- Use: artificial meadow - cultivated;

- Parent substrate: alluvium.

I $0-24 \mathrm{~cm}$ : surface layer is less overgrown with meadow vegetation with shallow root system, brown in colour, with fine granular structure and sandy loam texture $($ sand $=65.4 \%$, powder $=18.7 \%$, clay $=15.9 \%$ ).

II $24-82 \mathrm{~cm}$ : this layer shows evident traces of rotten plant parts, its structure is finely granular, colour is yellowish brown, and texture sandy loam (sand $=$ $56.9 \%$, powder $=22.5 \%$, clay $=20.6 \%$ ).

III $82-115 \mathrm{~cm}$ : abrupt transition to a layer of grayish-brown colour with evident traces of rotten plants, fine granular structure and sandy clayey loam texture ( sand $=55.2 \%$, powder $=23.0 \%$, clay $=21.8 \%$ ).

IV $>115 \mathrm{~cm}$ : emergence of groundwater. 

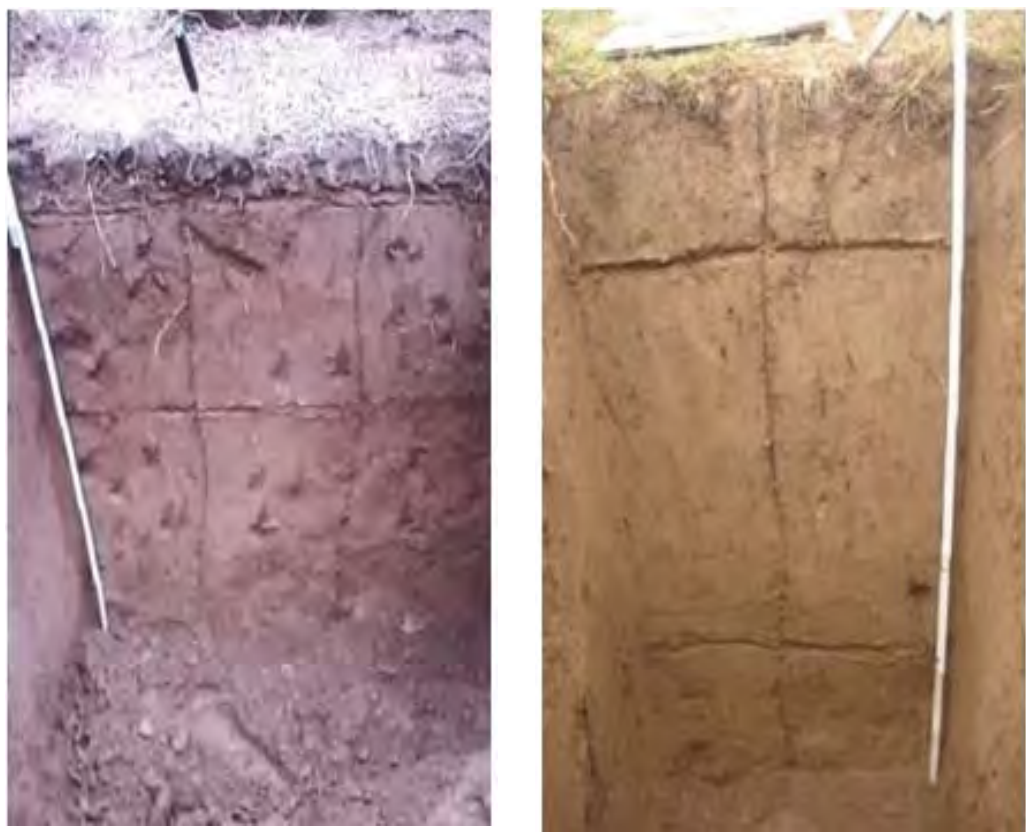

Figure 3 - 4. Profiles of soil at the sites BUK (left) and KLISA (right)

\section{Physical properties of soil}

The stability of structural aggregates in the depth of the profile was very good, good to unstable. Mechanical composition in the surface layer was lighter- sandy loams, and heavier in deeper layers - sandy clayey loams. The soils were porous (KLISA: $51.48 \pm$ 0.42; BUK: $47.51 \pm 0.91$ ), with medium soil water (KLISA: 42.36 \pm 0.70 ; BUK: 38.72 \pm 0.52 ) and moderate soil air capacities (KLISA: $9.14 \pm 0.44$; BUK: $8.57 \pm 1.01$ ).

\section{Chemical properties of average samples of soil $0-20 \mathrm{~cm}$}

In average samples the reactions of $\mathrm{pH}$ values of BUK and KLISA ranged from slightly to very alkaline with an upward trend with the profile depth. The contents of $\mathrm{P}_{2} \mathrm{O}_{5}, \mathrm{~K}_{2} \mathrm{O}$ and humus were low and deteriorated rapidly with the depth. Total content of $\mathrm{CaCO}_{3}$ was high with a tendency of increase with the profile depth. Mean values of measured electro-conductivity of the soil were not indicative of soil salinity at the profile. Results of the observed chemical parameters in samples $(0-20 \mathrm{~cm})$ are shown in Table 1. 
Table 1 . The chemical properties in average samples $(\Sigma n=3)$

\begin{tabular}{|c|c|c|c|c|c|c|}
\hline \multicolumn{2}{|c|}{ Parameters } & \multirow{2}{*}{$\begin{array}{c}\mathbf{X}_{\mathbf{m v}} \pm \mathbf{X}_{\mathbf{s e}} \\
8.27 \pm 0,03\end{array}$} & \multirow{2}{*}{$\frac{\min }{8.14}$} & \multirow{2}{*}{$\frac{\max }{8.35}$} & \multirow{2}{*}{$\frac{\mathbf{V}}{0.01}$} & \multirow{2}{*}{$\frac{\boldsymbol{\sigma}}{0.07}$} \\
\hline & BUK & & & & & \\
\hline in $\mathrm{H}_{2} \mathrm{O}$ & KLISA & $8.35 \pm 0,04$ & 8.20 & 8.47 & 0.01 & 0.09 \\
\hline \multirow{2}{*}{$\begin{array}{l}\text { pH } \\
\text { in } \mathrm{KCl}\end{array}$} & BUK & $7.43 \pm 0,02$ & 7.35 & 7.51 & 0.00 & 0.05 \\
\hline & KLISA & $7.46 \pm 0,01$ & 7.42 & 7.50 & 0.00 & 0.02 \\
\hline \multirow{2}{*}{$\begin{array}{l}\mathrm{K}_{2} \mathrm{O} \\
(\mathrm{mg} / 100 \mathrm{~g} \text { tla })\end{array}$} & BUK & $9.83 \pm 1,41$ & 6.20 & 14.50 & 12.05 & 3.47 \\
\hline & KLISA & $7.25 \pm 0,28$ & 6.50 & 8.20 & 0.46 & 0.68 \\
\hline \multirow{2}{*}{$\begin{array}{l}\mathrm{P}_{2} \mathrm{O}_{5} \\
(\mathrm{mg} / 100 \mathrm{~g} \text { tla })\end{array}$} & BUK & $4.82 \pm 0,41$ & 3.76 & 6.03 & 1.10 & 1.00 \\
\hline & KLISA & $5.63 \pm 0,20$ & 5.00 & 6.34 & 0.24 & 0.49 \\
\hline \multirow{2}{*}{$\begin{array}{l}\text { Humus } \\
(\%)\end{array}$} & BUK & $2.33 \pm 0,29$ & 1.64 & 3.04 & 0.50 & 0.71 \\
\hline & KLISA & $1.54 \pm 0,01$ & 1.53 & 1.57 & 0.00 & 0.01 \\
\hline \multirow{2}{*}{$\begin{array}{l}\mathrm{CaCO}_{3} \\
(\%)\end{array}$} & BUK & $62.79 \pm 0,77$ & 60.84 & 65.97 & 3.58 & 1.89 \\
\hline & KLISA & $33.35 \pm 0,49$ & 31.52 & 35.18 & 1.44 & 1.20 \\
\hline
\end{tabular}

Designation: „BUK“ - natural meadow, „KLISA“ - artificial meadow, $\mathrm{n}$ - number of samples,

$X_{\mathrm{mv}}-$ mean value, $X_{\mathrm{se}}$ - statistical error, min - minimal value, max - maximum value,

$\mathrm{V}$ - variance, $\sigma$ - deviation

\section{Distribution of the total contents of $\mathrm{Cd}$, Ni and As in average samples}

In average samples at the sites of BUK and KLISA $(0-10$ and $0-20 \mathrm{~cm})$, a significant difference $(\mathrm{p} \leq 0.05)$ in the total content of $\mathrm{Cd}, \mathrm{Ni}$ and As was established (Table 2).

Table 2. Distribution of the total contents of $\mathrm{Cd}, \mathrm{Ni}$ and As in average samples

\begin{tabular}{|c|c|c|c|c|c|c|c|c|}
\hline \multicolumn{2}{|c|}{ Observed } & $\mathbf{X}_{\mathbf{m v}} \pm \mathbf{X}_{\mathbf{s e}}$ & $\min$ & $\max$ & $\mathbf{V}$ & $\Sigma$ & $\chi^{2}$ & $\mathbf{p}$ \\
\hline \multicolumn{9}{|c|}{ Depth0 $-10 \mathrm{~cm}(\Sigma \mathrm{n}=3)$} \\
\hline \multirow{2}{*}{$\begin{array}{l}\mathrm{Cd} \\
(\mathrm{mg} / \mathrm{kg})\end{array}$} & BUK & $0.70 \pm 0.01$ & 0.69 & 0.71 & 0.00 & 0.01 & & \\
\hline & KLISA & $0.94 \pm 0.00$ & 0.94 & 0.95 & 0.00 & 0.01 & 3.95 & $\mathrm{p} \leq 0.05$ \\
\hline \multirow{2}{*}{$\begin{array}{l}\mathrm{Ni} \\
(\mathrm{mg} / \mathrm{kg})\end{array}$} & BUK & $39.54 \pm 0.01$ & 39.52 & 39.55 & 0.00 & 0.01 & & \\
\hline & KLISA & $36.01 \pm 0.02$ & 35.99 & 36.05 & 0.00 & 0.03 & 3.97 & $\mathrm{p} \leq 0.05$ \\
\hline \multirow{2}{*}{$\begin{array}{l}\text { As } \\
(\mathrm{mg} / \mathrm{kg})\end{array}$} & BUK & $4.40 \pm 0.01$ & 4.39 & 4.42 & 0.00 & 0.01 & & \\
\hline & KLISA & $5.89 \pm 0.00$ & 5.89 & 5.90 & 0.00 & 0.01 & 3.97 & $\mathrm{p} \leq 0.05$ \\
\hline
\end{tabular}




\begin{tabular}{|c|c|c|c|c|c|c|c|c|}
\hline \multicolumn{2}{|c|}{ Observed } & $\mathbf{X}_{\mathbf{m v}} \pm \mathbf{X}_{\mathbf{s e}}$ & $\min$ & $\max$ & $\mathbf{V}$ & $\Sigma$ & $\chi^{2}$ & $\mathbf{p}$ \\
\hline \multicolumn{9}{|c|}{ Depth $0-20$ cm $(\Sigma n=3)$} \\
\hline \multirow{2}{*}{$\begin{array}{l}\mathrm{Cd} \\
(\mathrm{mg} / \mathrm{kg})\end{array}$} & BUK & $0.52 \pm 0.07$ & 0.33 & 0.71 & 0.03 & 0.18 & & \\
\hline & KLISA & $0.95 \pm 0.00$ & 0.94 & 0.96 & 0.00 & 0.01 & 3.95 & $p \leq 0.05$ \\
\hline \multirow{2}{*}{$\begin{array}{l}\mathrm{Ni} \\
(\mathbf{m g} / \mathbf{k g})\end{array}$} & BUK & $34.87 \pm 1.90$ & 30.20 & 39.55 & 26.13 & 5.11 & & \\
\hline & KLISA & $39.33 \pm 1.35$ & 35.99 & 42.66 & 13.22 & 3.63 & 2.09 & $\mathrm{p} \leq 0.05$ \\
\hline \multirow{2}{*}{$\begin{array}{l}\text { As } \\
(\mathrm{mg} / \mathrm{kg})\end{array}$} & BUK & $4.30 \pm 0.04$ & 4.20 & 4.42 & 0.01 & 0.11 & & \\
\hline & KLISA & $6.15 \pm 0.11$ & 5.89 & 6.41 & 0.07 & 0.27 & 8.48 & $\mathrm{p} \leq 0.05$ \\
\hline
\end{tabular}

Designation: „BUK“ - natural meadow, „KLISA“ - artificial meadow, n - number of samples,

$X_{\mathrm{mv}}$ - mean value, $\mathrm{X}_{\mathrm{se}}$ - statistical error, min - minimal value, max - maximum value, $\mathrm{V}$ - variance, $\sigma$ - deviation, $\chi^{2}-$ Kruskal - Wallis coefficient; $p$ - level of significance

In the average samples at the sites of BUK and KLISA $(0-10 \mathrm{~cm})$, total mean contents of $\mathrm{Cd}$ and As were lower than the permitted levels of MRL-OF and MRL $\left(\mathrm{Cd}_{\mathrm{BUK}}=0.70\right.$ $\mathrm{mg} / \mathrm{kg} ; \mathrm{Cd}_{\mathrm{KLISA}}=0.94 \mathrm{mg} / \mathrm{kg} ; \mathrm{As}_{\mathrm{BUK}}=4.40 \mathrm{mg} / \mathrm{kg} ; \mathrm{As}_{\mathrm{KLISA}}=5.89 \mathrm{mg} / \mathrm{kg}$ ), while the content of $\mathrm{Ni}$ was bordered MRL and exceeded MRL-OF $\left(\mathrm{Ni}_{\mathrm{BUK}}=39.54 \mathrm{mg} / \mathrm{kg}\right.$; $\mathrm{Ni}_{\text {KLISA }}$ $=36.01 \mathrm{mg} / \mathrm{kg})$. In the samples from the site of BUK $(0-20 \mathrm{~cm})$, total mean contents of $\mathrm{Cd}$ and As were below the level of MRL-OF and MRL $\left(\mathrm{Cd}_{\mathrm{BUK}}=0.52 \mathrm{mg} / \mathrm{kg}\right.$; $\mathrm{As}_{\mathrm{BUK}}=$ $4.30 \mathrm{mg} / \mathrm{kg}$ ), while $\mathrm{Ni}$ had a tendency of slight decrease compared to the average samples $0-10 \mathrm{~cm}\left(\mathrm{Ni}_{\text {BUK }} 39.54\right.$ to $34.87 \mathrm{mg} / \mathrm{kg}$ ). In the samples from the site of KLISA $(0-20 \mathrm{~cm})$, total content of Cd remained the same $(0.95 \mathrm{mg} / \mathrm{kg})$ while the contents of $\mathrm{Ni}$ and As were slightly increased compared to the average samples $0-10 \mathrm{~cm}\left(\mathrm{Ni}_{\mathrm{KLISA}} 36.01\right.$ to $39.33 \mathrm{mg} / \mathrm{kg}$; As KLISA $_{5.89}$ to $6.15 \mathrm{mg} / \mathrm{kg}$ ). Given that these alluvial plains were formed by deposition of allochthonous matter from the surrounding areas and affected by frequent, it is generally difficult to define a single tendency of increase or decrease of total content of $\mathrm{Cd}, \mathrm{Ni}$ and As in the analyzed average samples (Figure 5-7).
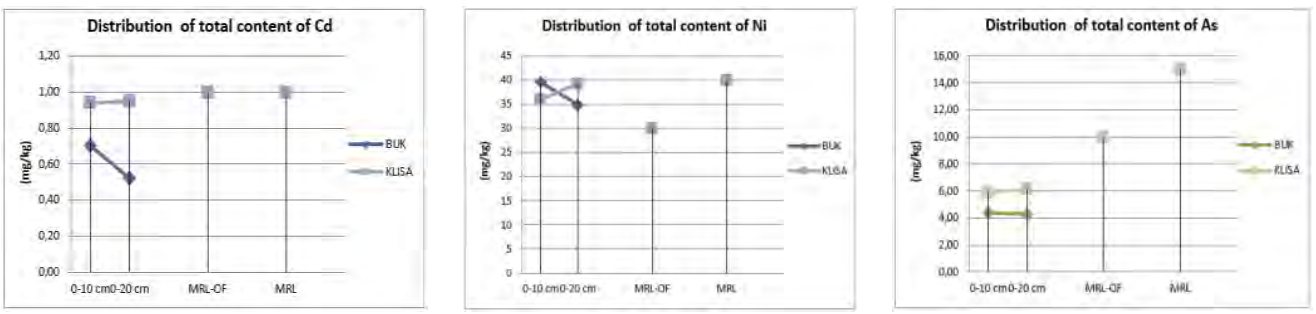

Figure 5-7. Distribution of the total content of $\mathrm{Cd}$, $\mathrm{Ni}$ and $\mathrm{As}$ in average samples 


\section{Distribution of the total content of $\mathrm{Cd}$, Ni and As in the soil profiles}

Results of the analysed profiles at BUK and KLISA sites of different use (natural and artificial meadow) have shown significant differences $(\mathrm{p} \leq 0.05)$ in concentrations of $\mathrm{Ni}$ and As, and no differences ( $>0.05)$ in Cd (Table 5).

Table 5. Distribution of the total content of $\mathrm{Cd}, \mathrm{Ni}$ i As in the soil profiles

\begin{tabular}{|c|c|c|c|c|c|c|c|c|}
\hline Ob & ved & $\mathbf{X}_{\mathrm{sr}} \pm \mathbf{X}_{\mathrm{sg}}$ & $\min$ & $\max$ & $\mathbf{V}$ & $\boldsymbol{\sigma}$ & $\chi^{2}$ & $\mathbf{p}$ \\
\hline \multicolumn{9}{|c|}{$\left(\Sigma n_{\text {BUK-KLISA }}=18\right)$} \\
\hline \multirow{2}{*}{$\begin{array}{l}\mathrm{Cd} \\
(\mathrm{mg} / \mathrm{kg})\end{array}$} & BUK & $0.32 \pm 0.13$ & $<0.01$ & 0.96 & 0.17 & 0.41 & \multirow{2}{*}{0.88} & \multirow{2}{*}{$\mathrm{p}>0.05$} \\
\hline & KLISA & $0.41 \pm 0.08$ & 0.17 & 0.74 & 0.05 & 0.24 & & \\
\hline \multirow{2}{*}{$\begin{array}{l}\mathrm{Ni} \\
(\mathrm{mg} / \mathbf{k g})\end{array}$} & BUK & $48.87 \pm 1.00$ & 44.86 & 51.12 & 9.02 & 3.00 & \multirow{2}{*}{7.76} & \multirow{2}{*}{$\mathrm{p} \leq 0.05$} \\
\hline & KLISA & $41.16 \pm 1.99$ & 34.60 & 48.44 & 35.99 & 5.99 & & \\
\hline \multirow{2}{*}{$\begin{array}{l}\text { As } \\
(\mathrm{mg} / \mathrm{kg})\end{array}$} & BUK & $4.94 \pm 0.14$ & 4.38 & 5.40 & 0.18 & 0.43 & \multirow{2}{*}{3.96} & \multirow{2}{*}{$\mathrm{p} \leq 0.05$} \\
\hline & KLISA & $5.41 \pm 0.19$ & 4.69 & 6.10 & 0.34 & 0.58 & & \\
\hline
\end{tabular}

Designation: „BUK“ - natural meadow; „KLISA“ - artificial meadow, $\mathrm{n}$ - number of samples,

$X_{\mathrm{mv}}-$ mean value, $X_{\mathrm{se}}$ - statistical error, min - minimal value, max - maximum value,

$\mathrm{V}$ - variance, $\sigma$ - deviation, $\chi^{2}-$ Kruskal - Wallis coefficient; $\mathrm{p}$ - level of significance

In the studied profiles at the sites of BUK and KLISA, the total mean contents had a downward trend $\left(\mathrm{Cd}_{\mathrm{BUK}} 0.96\right.$ to $<0.01 \mathrm{mg} / \mathrm{kg}, \mathrm{Cd}_{\mathrm{KLISA}} 0.74$ to $0.17 \mathrm{mg} / \mathrm{kg}, \mathrm{Ni}_{\mathrm{BUK}} 51.12$ to $44.86 \mathrm{mg} / \mathrm{kg}$, Ni KLISA 48.44 to $34.60 \mathrm{mg} / \mathrm{kg}$, As BUK 5.40 to $4.38 \mathrm{mg} / \mathrm{kg}$, As KLISA 6.10 to $4.69 \mathrm{mg} / \mathrm{kg}$ ). In both profiles of the alluvial soil of different use a single tendency of decline of total contents with the increase in depth, i.e. from the surface to the bottom of the profile, was observed in all three analysed elements (Figure $8-10$ ).
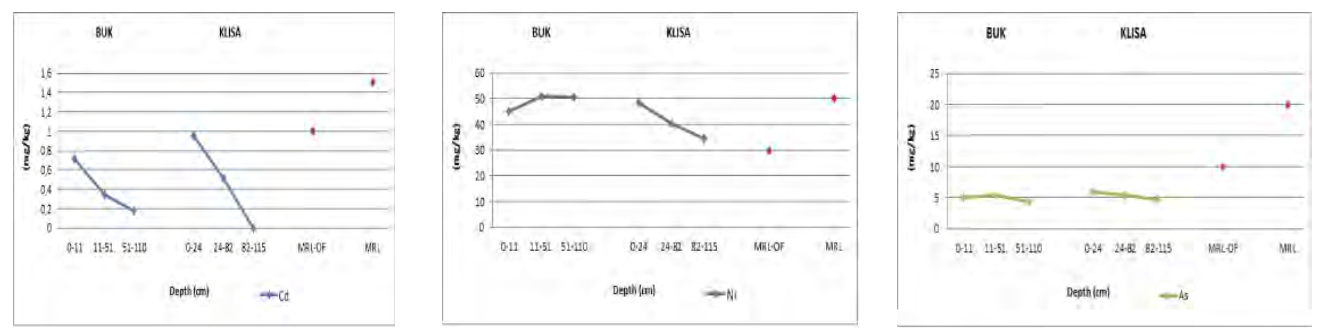

Figure $8-10$. Distribution of the total content of $\mathrm{Cd}$, Ni and As in soil profiles 


\section{CONCLUSIONS}

At the sites of BUK and KLISA, according to the physical and chemical parameters of soil, stability of structural aggregates declines from very good to unstable; mechanical composition of the soil in the surface layer - sandy loams, and in the deeper ones - sandy clay loam. The soils are porous and with medium water and moderate air capacity. In the average samples at the sites $(0-10 \mathrm{~cm}$ and $0-20 \mathrm{~cm})$, total mean contents of $\mathrm{Cd}$ and As were lower than the permitted levels of MRL-OF and $\operatorname{MRL}\left(\mathrm{Cd}_{\mathrm{BUK}}=0.70 \mathrm{mg} / \mathrm{kg} ; \mathrm{Cd}_{\mathrm{KLISA}}=0.94 \mathrm{mg} / \mathrm{kg} ; \mathrm{As}_{\mathrm{BUK}}=4.40 \mathrm{mg} / \mathrm{kg} ; \mathrm{As}_{\mathrm{KLISA}}=5.89\right.$ $\mathrm{mg} / \mathrm{kg}$ ), while the content of Ni was bordered MRL and exceeded MRL-OF (NiKLISA $=36.01 \mathrm{mg} / \mathrm{kg} ; \mathrm{Ni}_{\text {BUK }}=39.54 \mathrm{mg} / \mathrm{kg}$ ). In general, the $\mathrm{pH}$ levels established at the sites of BUK and KLISA ranged from slightly to very alkaline with an upward trend with the profile depth ( $\mathrm{pH}_{\mathrm{BUK}}$ in $\mathrm{H} 208.09$ to $8.45 ; \mathrm{pH}_{\mathrm{BUK}}$ in KCl 8.18 to $8.52 ; \mathrm{pH}_{\mathrm{KLISA}}$ in $\mathrm{H}_{20} 7.35$ to 7.56; $\mathrm{pH}_{\mathrm{KLISA}}$ in $\mathrm{KCl} 7.42$ to 7.60). In the surface layer, contents of $\mathrm{P}_{2} \mathrm{O}_{5}, \mathrm{~K}_{2} \mathrm{O}$ and humus were low and decreased with the depth of soil. The content of calcium carbonate was high with a tendency to increase with depth $\left(\mathrm{CaC}_{3 \text { вик }} 31.52\right.$ to $65.97 \%$; $\mathrm{CaCO}_{3 \mathrm{KLISA}} 20.52$ to $41.78 \%$ ). The measured levels of soil electrical conductivity were not indicative of the soil salinity. In the distribution of $\mathrm{Cd}, \mathrm{Ni}$ and $\mathrm{As}$ in the average samples taken from the sites of BUK and KLISA a significant difference $(p \leq 0.05)$ was established in the total content of $\mathrm{Cd}$, Ni and As. Generally, in average samples it was difficult to define a single tendency of distribution (increase or decrease) of the total content of $\mathrm{Cd}, \mathrm{Ni}$ and As. In the profiles at the sites (BUK and KLISA), significant differences $(p \leq 0.05)$ were determined in the total content of $\mathrm{Ni}$ and $\mathrm{As}$, and no significant difference $(p>0.05)$ for Cd. Generally, for the sites of BUK and KLISA it was established that the distribution of the content of $\mathrm{Cd}, \mathrm{Ni}$ and $\mathrm{AS}$ in the profiles decreased in relation to the depth $\left(\mathrm{Cd}_{\mathrm{BUK}} 0.96\right.$ to $<0.01 \mathrm{mg} / \mathrm{kg}$; $\mathrm{Cd}_{\mathrm{KLISA}} 0.74$ to 0.17 $\mathrm{mg} / \mathrm{kg}$; $\mathrm{Ni}_{\text {BUK }} 51.12$ to $44.86 \mathrm{mg} / \mathrm{kg}$; Ni KLISA 48.44 to $34.60 \mathrm{mg} / \mathrm{kg}$; $\mathrm{As}_{\text {BUK }} 5.40$ to 4.38 $\mathrm{mg} / \mathrm{kg}$; As KLISA 6.10 to $4.69 \mathrm{mg} / \mathrm{kg}$ ).

\section{REFERENCES}

Alibabić, V. and Bašić, F. 2005. State and Projection sound development of agriculture and industry in the area of influence of the National Park „Una“, Feasibility Study, Bihac, p. 147.

Bašić, F. and Čustović, H. 2005. Use, management and protection of soil in the area of the National Park „Una“, Feasibility Study, Zagreb, p. 45.

Dellantonio. A. Fitz. W. J., Čustović H., Repmann. F., Schneider. B. U., Grunewald. H., Gruber., V., Zgorelec. Z., Zerem. N., Carter. C., Marković, M., Puschenreiter, M., Wenzel, W. W. 2007. Environmental risks of farmed and barren alkaline coal ash landfills in Tuzla, Bosnia and Herzegovina. Environmental Pollution., ISSN 02692491, vol.153, No.3, pp. 677-686. Available: www.sciencedirect.com 
Dheeba, B. and Sampathkumar, P. 2012. Evaluation of Heavy Metal Contamination in Sufrace Soil around industrial Area, Tamil Nadu, India. International Journal of ChemTech Research, vol.4, No.3, pp. 1299-1240.

Kruskal, W. H., Wallis, W. A. 1952. Use of Ranks in One-Criterion Variance Analysis. Journal of the American Statistical Association 47, 583.

Maksimović, T., Ilić, P., Lolić, S. 2013. Seasonal distribution of heavy metals (Fe, Mn, Zn, $\mathrm{Cu}, \mathrm{Cd}$ and $\mathrm{Pb}$ ) in Phragmites communis TRIN., In the area of the pond Bardača. Scientific Conference "Environment between science and practice - state and prospects". Institute for the Protection and Ecology, Banja Luka, p. 247-252.

Muhamedagić, F. 2010. The soil as a factor in the sustainability of the ecosystem in the area of the National Park „Una“, master thesis, Faculty of Agricultural and Food Science, University of Sarajevo, Sarajevo, p. 110.

Muhamedagić, F. 2015. Factors distribution of cadmium, nickel and arsenic in the area of the National Park „Una“ and the possibility of their phytoremediation, doctoral dissertation, Faculty of Biotechnology, University of Bihac, Bihac, p. 137.

Official Gazette of the Federation of B\&H, No. 72/09. Rules on determining the allowable amount of hazardous substances in soil and methods there of.

Romić, M. and Romić, D. 2003. Heavy metals distribution in agricultural topsoils in urban area. Environmental Geology 43, pp. 795-805.

Shakeri, A., Moore, F., Modabber, S. 2009. Heavy Metal Contamination and Distribution in the Shiraz Industrial Complex Zone Soil, South Siraz, Iran. World Applied Sciences Journal 6(3):413-425. 